\title{
Emerging Scholar Best Article Award, 2017
}

\author{
Roger J. R. Levesque ${ }^{1}$
}

Received: 9 September 2017 / Accepted: 12 September 2017 / Published online: 22 September 2017

(C) Springer Science+Business Media, LLC 2017

The editors of the Journal of Youth and Adolescence are very pleased to announce the 2017 recipient of its Emerging Scholar Best Article Award. This award goes to the article's lead author, who must be an "emerging scholar" (i.e., an untenured researcher, such as a graduate student, postdoctoral scholar, research scientist, or assistant professor). The recipient of the award is selected by a random group of editorial board members who evaluate a volume's manuscripts on the basis of their innovative and substantive contributions to the empirical understanding of adolescence. In addition to receiving the recognition from colleagues, the winner receives a financial award generously provided by Springer, the journal's publisher.

The 2017 winner is Chia-chen Yang, for her article entitled "Online self-presentation on Facebook and self development during the college transition," which was coauthored with Bradford Brown (Yang and Brown, 2016). Their study focused on youth's self-presentation as they transition to a residential college and adjust to their new environment. The authors found that students become less guarded in their self-presentation after they spend some time in the university. Although becoming less guarded may be seen as problematic, it turns out that revealing diverse and deep aspects of one's life, and doing so while remaining positive and authentic, invites supportive feedback, which associates with self-esteem. That feedback may explain why, in the long run, students' self-esteem receives a boost when they think carefully about their online

Roger J. R. Levesque

rlevesqu@indiana.edu

Indiana University, 302 Sycamore Hall, Bloomington, IN, USA self-presentations. Yang and Brown's line of research reveals the importance of social networking sites in easing significant developmental transitions as they allow youth to claim a sense of identity through social connections.

The journal's editors view receiving the award as a considerably distinctive accomplishment. The journal publishes 12 issues per year, each typically containing about 16 manuscripts. In addition, it is notable that, every year, more and more first authors no longer are emerging scholars. This means that there fewer emerging scholars qualify to be considered. These shifts in authorship may be seen as reducing the competitiveness of the award. However, these developments actually make the process even more competitive for emerging scholars, as they have increased competition to get published in the journal in the first place. In fact, the majority of submissions (from emerging scholars and others alike) now are "desk rejected".

The selection process resulted in a pool of very impressive articles. This is similar to prior years (see Levesque 2011, 2012, 2013, 2014, 2015a, 2016a). Unlike prior years, however, there appears to be much less variation in the range of topics that emerged. In fact, all of the articles selected from each journal issue are notable for their focus on relationships and their influence on development. Some focus on youth's social experiences in different social service systems (Baglivio et al 2016) and the nature of school environments (Bottiani et al. 2016; Poteat et al. 2016; Tanner-Smith and Fisher 2016). Others examined developmental influences of peers (Greischel et al. 2016), romantic partners (Boisvert and Poulin 2016), the media (McLean et al. 2016) and parents (Hannigan et al. 2016; Korelitz and Garber (2016) as well as perceptions of being alone (Maes et al 2016) and of being involved in unwanted relationships (Festl and Quandt, 2016). Focusing on the 
general topics of the manuscripts, however, misses one of their most important features. The studies are marked by increasing complexity, particularly in the number of factors that they address to help ensure robustness and replicability (see Levesque, 2015b, 2016b).

On behalf of the journal's editorial board, I would like to congratulate Professor Chia-chen Yang and her colleague, Professor Bradford Brown. Their recognition comes at a remarkable time in the growth of our journal and field.

\section{Compliance with Ethical Standards}

Conflict of Interest The author declares that he has no competing interests.

\section{References}

Baglivio, M. T., Wolff, K. T., Piquero, A. R., Bilchik, S., Jackowski, K., Greenwald, M. A., \& Epps, N. (2016). Maltreatment, child welfare, and recidivism in a sample of deep-end crossover youth. Journal of Youth and Adolescence, 45(4), 625-654.

Boisvert, S., \& Poulin, F. (2016). Romantic relationship patterns from adolescence to emerging adulthood: Associations with family and peer experiences in early adolescence. Journal of Youth and Adolescence, 45(5), 945-958.

Bottiani, J. H., Bradshaw, C. P., \& Mendelson, T. (2016). Inequality in Black and White high school students' perceptions of school support: An examination of race in context. Journal of Youth and Adolescence, 45(6), 1176-1191.

Festl, R., \& Quandt, T. (2016). The role of online communication in long-term cyberbullying involvement among girls and boys. Journal of Youth and Adolescence, 45(9), 1931-1945.

Greischel, H., Noack, P., \& Neyer, F. J. (2016). Sailing uncharted waters: Adolescent personality development and social relationship experiences during a year abroad. Journal of Youth and Adolescence, 45(11), 2307-2320.

Hannigan, L. J., McAdams, T. A., Plomin, R., \& Eley, T. C. (2016). Etiological influences on perceptions of parenting: A longitudinal, multi-informant twin study. Journal of Youth and Adolescence, 45(12), 2387-2405.

Korelitz, K. E., \& Garber, J. (2016). Congruence of parents' and children's perceptions of parenting: A meta-analysis. Journal of Youth and Adolescence, 45(10), 1973-1995.
Levesque, R. J. R. (2011). Emerging scholar best article award, 2011. Journal of Youth and Adolescence, 40, 565-1567.

Levesque, R. J. R. (2012). Emerging scholar best article award, 2012. Journal of Youth and Adolescence, 41, 1557-1559.

Levesque, R. J. R. (2013). Emerging scholar best article award, 2013. Journal of Youth and Adolescence, 42, 1910-1912.

Levesque, R. J. R. (2014). Emerging scholar best article award, 2014. Journal of Youth and Adolescence, 43, 2091-2092.

Levesque, R. J. R. (2015a). Emerging scholar best article award, 2015. Journal of Youth and Adolescence, 44, 2395-2396.

Levesque, R. J. R. (2015b). Statistical guidelines for publishing in the Journal of Youth and Adolescence. Journal of Youth and Adolescence, 44(12), 2391-2394.

Levesque, R. J. R. (2016a). Emerging scholar best article award, 2016. Journal of Youth and Adolescence, 45, 2497-2498.

Levesque, R. J. R. (2016b). Reviews in research on adolescence: Genres, trends, and challenges. Adolescent Research Review, $1(1), 3-13$.

Maes, M., Vanhalst, J., Spithoven, A. W., Van den Noortgate, W., \& Goossens, L. (2016). Loneliness and attitudes toward aloneness in adolescence: A person-centered approach. Journal of Youth and Adolescence, 45(3), 547-567.

McLean, S. A., Paxton, S. J., \& Wertheim, E. H. (2016). Does media literacy mitigate risk for reduced body satisfaction following exposure to thin-ideal media? Journal of Youth and Adolescence, 45(8), 1678-1695.

Poteat, V. P., Calzo, J. P., \& Yoshikawa, H. (2016). Promoting youth agency through dimensions of gay-straight alliance involvement and conditions that maximize associations. Journal of Youth and Adolescence, 45(7), 1438-1451.

Tanner-Smith, E. E., \& Fisher, B. W. (2016). Visible school security measures and student academic performance, attendance, and postsecondary aspirations. Journal of Youth and Adolescence, 45(1), 195-210.

Yang, C. C., \& Brown, B. B. (2016). Online self-presentation on facebook and self development during the college transition. Journal of Youth and Adolescence, 45(2), 402-416.

Roger J. R. Levesque is Professor of Criminal Justice and (Affiliate) Law, Indiana University. He serves as Editor-in-Chief of the Journal of Youth and Adolescence and the Adolescent Research Review. He also is editor of the Advancing Responsible Adolescent Development book series. 